\title{
The influence of sex, body weight, and renal function on the xylose test
}

\author{
MARTIN J. KENDALL AND SHEILA NUTTER \\ From the Gastrointestinal Laboratory, Queen Elizabeth Hospital, Birmingham 15
}

SUMMARY A low excretion of xylose may be due to malabsorption, renal disease, or old age. Malabsorption can be distinguished from other causes by performing a combined oral and intravenous test, the result being expressed as a fraction of these readings. Sex and body weight do not influence the xylose test.

Xylose is used to assess absorption because it is absorbed from the upper jejunum like glucose and fructose (Alvarado, 1966) and is excreted in the urine in amounts which reflect the quantity absorbed (Fordtran, Soergel, and Ingelfinger, 1962). The xylose test has the advantages of simplicity, painlessness, and repeatability. The disadvantage is that what is estimated depends not only on the efficiency of absorption but also on gastric emptying, metabolism, urinary excretion, and the rate of deterioration of the collected specimen. If more were known about factors influencing the various steps a more informed deduction about absorption would be possible.

Age has been shown to be a significant influence (Fowler and Cooke, 1960; Kendall, 1970) and the importance of renal function is obvious. This paper analyses the effects of sex and body weight and offers a solution to the problem of abnormal renal function.

\section{Patients and Methods}

Oral and intravenous xylose tests were performed as previously described (Kendall, 1970); after a $5 \mathrm{~g}$ dose of d-xylose urine was collected for the initial two and subsequent three hours, the results being given as two-hour and total five-hour values. Results have also been expressed as a fraction: the amount excreted after the oral dose Received for publication 15 July 1970. over that excreted in the same period after the same dose intravenously. However the xylose is given, renal impairment will produce a proportionate reduction, numerator and denominator being modified in the same way leaving the fraction unaltered. Malabsorption should produce a low oral result without affecting the intravenous one and the resultant fraction should therefore be small.

\section{SEX AND WEIGHT STUDIES}

These were based on 150 oral and 150 intravenous tests on medical inpatients unselected except to exclude any with gastrointestinal or renal disease. The influence of sex was analysed by collecting the patients into decade groups, thereby eliminating the age factor, and calculating the mean and standard deviation for males and females in each group. Similarly the influence of weight was obtained by collecting the patients into $10-\mathrm{kg}$ weight groups.

\section{RENAL FUNCTION}

Tests were performed on four groups. The first group consisted of 21 patients, mean age 38.3 years, with no organic disease. The second of 25 patients over 60 , mean age 66.7 years, was unselected except to exclude any with gastrointestinal or renal disease. In the third group were nine patients with renal disease, mean age 43.7 years, mean blood urea $71.3 \mathrm{mg} \%$. The fourth group was made up of 14 cases of histologically proven 
The influence of sex, body weight, and renal function on the xylose test

adult coeliac disease, mean age $44 \cdot 8$ years. Seven of the patients were on a normal diet and seven were treated with a gluten-free diet.

Intravenous xylose results have been used as a guide to excretory capacity and the oral/intravenous fractions for the patients in these four groups are given.

\section{Results}

SEX

Oral and intravenous results are given in Tables I and II. The consistently higher excretion values for females after an intravenous dose reflects their superior renal function as indicated by the lower blood urea values for females in each decade (Carmalt and Whitehead, 1969). No consistent pattern emerges from the oral results, possibly because better absorptive function by males counterbalances their poorer excretory capacity.

\section{BODY WEIGHT}

The oral results (Fig. 1) show no direct correlation between xylose excretion and body weight. Groups with the higher mean values are those containing younger patients as shown by the lower mean age. An essentially similar set of results was obtained when 150 intravenous tests were allocated to weight groups.

\section{RENAL FUNCTION}

The conventional two- and five-hour oral results in Fig. 2 show the overlap of low values due to old age, renal impairment, and malabsorption. When the same results are expressed as an oral/

\begin{tabular}{|c|c|c|c|c|c|c|c|c|c|}
\hline \multirow{2}{*}{$\begin{array}{l}\text { Age Group } \\
(y r)\end{array}$} & \multirow{2}{*}{$\begin{array}{l}\text { No. of } \\
\text { Patients }\end{array}$} & \multirow[t]{2}{*}{ Sex } & \multicolumn{2}{|c|}{ Two-hour Xylose Test (g) } & \multicolumn{2}{|c|}{ Five-hour Xylose Test (g) } & \multicolumn{2}{|c|}{ Males and Females } & \multirow{2}{*}{$\begin{array}{l}\text { Mean Blood } \\
\text { Urea } \\
(\mathrm{mg} / 100 \mathrm{ml})\end{array}$} \\
\hline & & & Males & Females & Males & Females & $\begin{array}{l}\text { Two-hour } \\
\text { Test }(g)\end{array}$ & $\begin{array}{l}\text { Five-hour } \\
\text { Test }(g)\end{array}$ & \\
\hline $10-20$ & $\begin{array}{l}3 \\
5\end{array}$ & $\begin{array}{l}\mathbf{M} \\
\mathbf{F}\end{array}$ & $1 \cdot 12 \pm 0 \cdot 14$ & $1.25 \pm 0.26$ & $1.97 \pm 0.37$ & $2 \cdot 28 \pm 0 \cdot 26$ & $1 \cdot 20 \pm 0.22$ & $2 \cdot 16 \pm 0 \cdot 33$ & $22 \cdot 4$ \\
\hline $21-30$ & $\begin{array}{l}14 \\
10\end{array}$ & $\begin{array}{l}\mathbf{M} \\
\mathbf{F}\end{array}$ & $1.09 \pm 0.22$ & $1 \cdot 14 \pm 0 \cdot 20$ & $1.91 \pm 0.31$ & $2.03 \pm 0.33$ & $1 \cdot 11 \pm 0.22$ & $1.96 \pm 0.31$ & $24 \cdot 2$ \\
\hline $31-40$ & $\begin{array}{l}10 \\
16\end{array}$ & $\begin{array}{l}\mathbf{M} \\
\mathbf{F}\end{array}$ & $1 \cdot 12 \pm 0 \cdot 2 J$ & $1.03 \pm 0.20$ & $1 \cdot 95 \pm 0.31$ & $1.83 \pm 0.34$ & $1.06 \pm 0.20$ & $1.88 \pm 0.33$ & $24 \cdot 8$ \\
\hline $41-50$ & $\begin{array}{r}7 \\
18\end{array}$ & $\begin{array}{l}\mathbf{M} \\
\mathbf{F}\end{array}$ & $1 \cdot 10 \pm 0 \cdot 28$ & $0 \cdot 86 \pm 0 \cdot 20$ & $1.70 \pm 0.30$ & $1.73 \pm 0.30$ & $0.93 \pm 0.24$ & $1.72 \pm 0.30$ & $26 \cdot 9$ \\
\hline $51-60$ & $\begin{array}{c}8 \\
17\end{array}$ & $\begin{array}{l}\mathbf{M} \\
\mathrm{F}\end{array}$ & $0.86 \pm 0.47$ & $0 \cdot 83 \pm 0 \cdot 17$ & $1.77 \pm 0.26$ & $1.47 \pm 0.20$ & $0.91 \pm 0.20$ & $1 \cdot 63 \pm 0 \cdot 28$ & $28 \cdot 9$ \\
\hline $61-70$ & $\begin{array}{l}15 \\
11\end{array}$ & $\begin{array}{l}\mathbf{M} \\
\mathbf{F}\end{array}$ & $0.79 \pm 0.14$ & $0.84 \pm 0.01$ & $1 \cdot 58 \pm 0.31$ & $1.63 \pm 0.24$ & $0.81 \pm 0.10$ & $1.60 \pm 0.28$ & $32 \cdot 5$ \\
\hline $71+$ & $\begin{array}{r}12 \\
4\end{array}$ & $\begin{array}{l}\mathbf{M} \\
\mathbf{F}\end{array}$ & 0.56 & $0.53 \pm 0.14$ & 1.09 & $0.98 \pm 0 \cdot 22$ & $0.54 \pm 0.01$ & $1.01 \pm 0.17$ & $34 \cdot 4$ \\
\hline
\end{tabular}

Table I Results of the oral xylose tests as means and standard deviations for males, females, and both combined, and the mean blood urea for each decade

\begin{tabular}{|c|c|c|c|c|c|c|c|c|c|}
\hline \multirow{2}{*}{$\begin{array}{l}\text { Age Group } \\
(y r)\end{array}$} & \multirow{2}{*}{$\begin{array}{l}\text { No. of } \\
\text { Patients }\end{array}$} & \multirow[t]{2}{*}{$\operatorname{Sex}$} & \multicolumn{2}{|c|}{ Two-hour Xylose Test (g) } & \multicolumn{2}{|c|}{ Five-hour Xylose Test (g) } & \multicolumn{2}{|c|}{ Males and Females } & \multirow{2}{*}{$\begin{array}{l}\text { Mean Blood } \\
\text { Urea } \\
(\mathrm{mg} / 100 \mathrm{ml})\end{array}$} \\
\hline & & & Males & Females & Males & Females & $\begin{array}{l}\text { Two-hour } \\
\text { Test }(g)\end{array}$ & $\begin{array}{l}\text { Five-hour } \\
\text { Test }(g)\end{array}$ & \\
\hline $10-20$ & $\begin{array}{l}7 \\
8\end{array}$ & $\begin{array}{l}\mathbf{M} \\
\mathbf{F}\end{array}$ & $2.00 \pm 0.38$ & $2 \cdot 11 \pm 0 \cdot 40$ & $2.62 \pm 0.33$ & $2.84 \pm 0.37$ & $2.06 \pm 0.37$ & $2.73 \pm 0.36$ & $20 \cdot 6$ \\
\hline $21-30$ & $\begin{array}{r}7 \\
10\end{array}$ & $\begin{array}{l}\mathbf{M} \\
\mathbf{F}\end{array}$ & $1 \cdot 88 \pm 0.22$ & $2.07 \pm 0.37$ & $2.59 \pm 0.40$ & $2 \cdot 72 \pm 0.42$ & $1.99 \pm 0.33$ & $2.67 \pm 0.40$ & $24 \cdot 0$ \\
\hline $31-40$ & $\begin{array}{r}6 \\
13\end{array}$ & $\begin{array}{l}\mathbf{M} \\
\mathbf{F}\end{array}$ & $1.94 \pm 0 \cdot 14$ & $2.01 \pm 0.30$ & $2.59 \pm 0.22$ & $2.66 \pm 0.37$ & $1.99 \pm 0.26$ & $2.64 \pm 0.33$ & $23 \cdot 8$ \\
\hline $41-50$ & $\begin{array}{r}9 \\
17\end{array}$ & $\begin{array}{l}\mathbf{M} \\
\mathbf{F}\end{array}$ & $1.74 \pm 0.37$ & $1 \cdot 80 \pm 0.24$ & $2.38 \pm 0.44$ & $2.44 \pm 0.30$ & $1 \cdot 78 \pm 0 \cdot 28$ & $2.42 \pm 0.34$ & $26 \cdot 6$ \\
\hline $51-60$ & $\begin{array}{l}18 \\
17\end{array}$ & $\begin{array}{l}\mathbf{M} \\
\mathbf{F}\end{array}$ & $1.45 \pm 0.30$ & $1 \cdot 60 \pm 0 \cdot 24$ & $2 \cdot 18 \pm 0 \cdot 31$ & $2.20 \pm 0.31$ & $1 \cdot 52 \pm 0 \cdot 28$ & $2 \cdot 19 \pm 0 \cdot 31$ & $27 \cdot 7$ \\
\hline $61-70$ & $\begin{array}{l}16 \\
14\end{array}$ & $\begin{array}{l}\mathbf{M} \\
\mathbf{F}\end{array}$ & $1 \cdot 41 \pm 0 \cdot 28$ & $1.49 \pm 0.26$ & $2.02 \pm 0.44$ & $2 \cdot 22 \pm 0 \cdot 28$ & $1.47 \pm 0.28$ & $2 \cdot 11 \pm 0 \cdot 38$ & $31 \cdot 8$ \\
\hline $71+$ & $\begin{array}{l}2 \\
6\end{array}$ & $\begin{array}{l}\mathbf{M} \\
\mathbf{F}\end{array}$ & $1 \cdot 10$ & $1 \cdot 10 \pm 0 \cdot 10$ & $1 \cdot 75$ & $1 \cdot 76 \pm 0.26$ & $1 \cdot 10 \pm 0 \cdot 22$ & $1.76 \pm 0.22$ & $36 \cdot 4$ \\
\hline
\end{tabular}

Table II Results of the intravenous xylose tests as means and standard deviations for males, females, and both combined, and the mean blood urea for each decade 


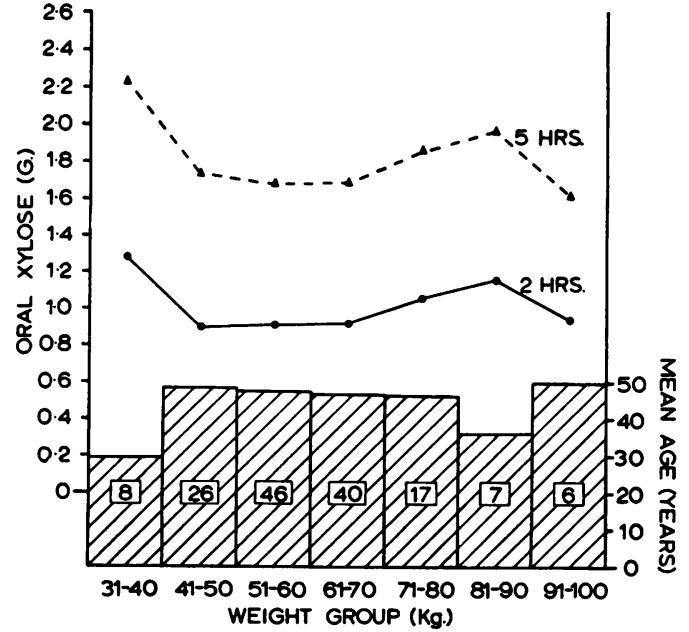

Fig. 1 Mean xylose excretions after a $5 \mathrm{~g}$ oral dose for $10 \mathrm{~kg}$ weight groups. The shaded areas indicate the mean age; the numbers in each group are shown. intravenous fraction (Fig. 3) the untreated coeliac cases are clearly distinguished from the other causes of low oral results, particularly at two hours. The highest two-hour oral/intravenous result for an untreated coeliac is $21 \%$ whereas from the lowest renal case it was $34 \%$; the lowest for an elderly patient was $36 \%$; and the results in the control group were all over $39 \%$.

\section{Discussion}

The use of a two-hour oral/intravenous fraction, which requires only one venepuncture and two short urine collections, makes the xylose test a useful diagnostic tool unaffected by age and renal function. Many patients with coeliac disease have a normal five-hour oral result, which may have given the test a poor reputation. The two-hour value and the two- over five-hour

\section{$\stackrel{\text { D }}{\stackrel{5}{+}}$ 음. $\overrightarrow{0}$ กิ

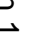

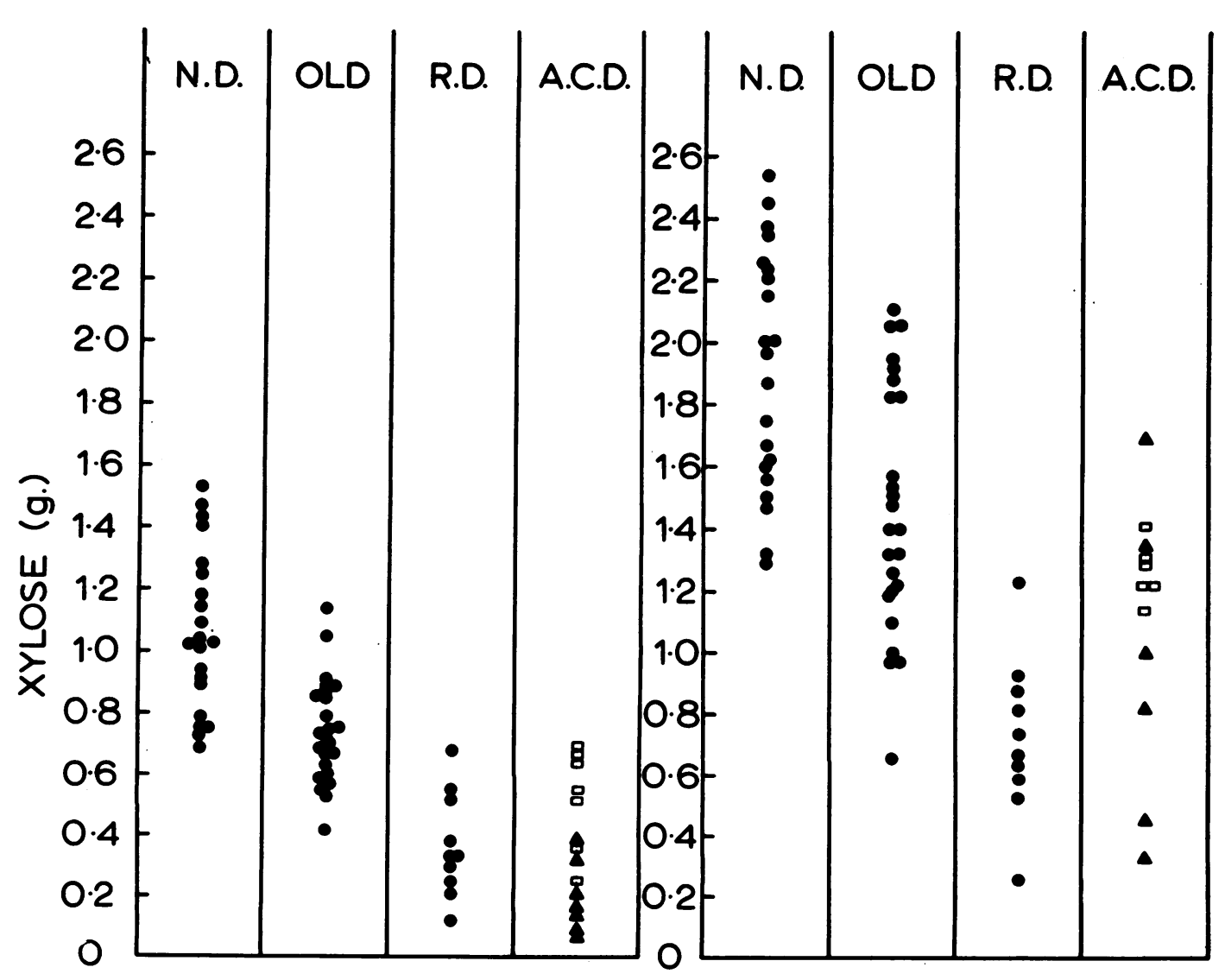

Fig. 2 Two-and five-hour oral xylose results for patients with nervous dyspepsia (N.D.), old patients, those with renal disease (R.D.), and adult coeliac disease (A.C.D.). Untreated coeliac patients are shown as triangles. 


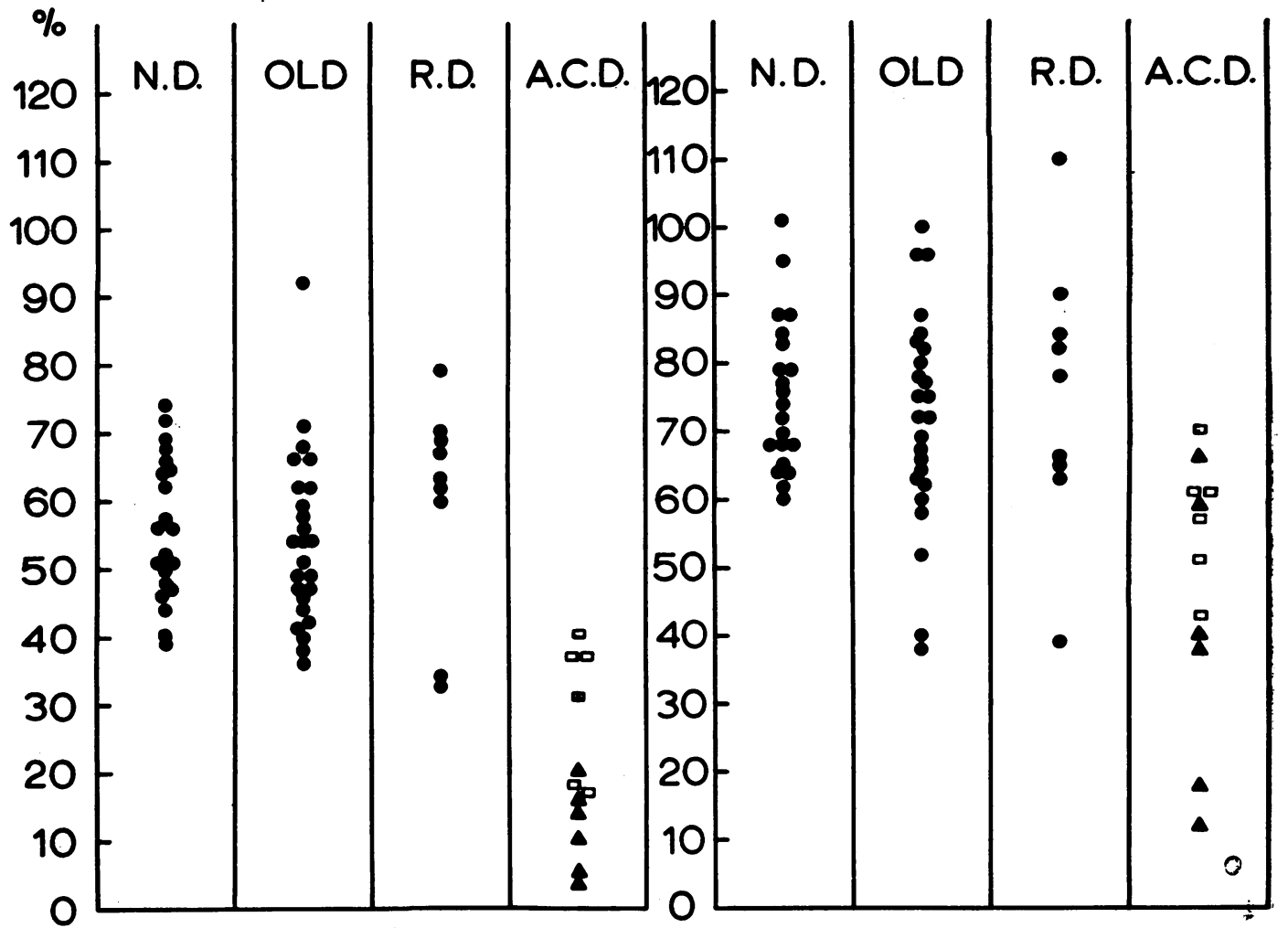

Fig. 3 Two- and five-hour oral/intravenous fractions for patients with nervous dyspepsia (N.D.) old patients, those with renal disease (R.D.), and adult coeliac disease (A.C.D.). Untreated coeliac patients are shown as triangles.

fraction have been shown to be better discriminants (Sammons, Morgan, Frazer, Montgomery, Philip, and Phillips, 1967). The oral/intravenous fraction is independent of renal function and clearly distinguishes malabsorption from other causes of low values; the correlation of xylose excretion with blood urea, serum creatinine, and creatinine clearance is not close enough to use any of these in an individual case to correct for renal impairment (unpublished observations).

The results show that neither the sex nor the weight of the patient need be considered when interpreting the xylose test.

We should like to thank Dr C.F. Hawkins for his help and advice, and the staff of the Queen

Elizabeth Hospital Pharmacy, who prepared all the intravenous xylose. The work was supported by funds provided by the United Birmingham Hospitals Endowment Fund.

\section{References}

Alvarado, F. (1966). D-xylose active transport in the hamster small intestine. Biochim. biophys. Acta (Amst.), 112, 292-306.

Carmalt, M. H. B., and Whitehead, T. P. (1969). Personal communication.

Fordtran, J. S., Soergel, K. H., and Ingelfinger, F. J. (1962). Intestinal absorption of D-xylose in man. New Engl. J. Med., 267, 274-279.

Fowler, D., and Cooke, W. T. (1960). Diagnostic significance of D xylose excretion test. Gut, 1, 67-70.

Kendall, M. J. (1970). The influence of age on the xylose test. Gut, 11, 498-501.

Sammons, H. G., Morgan, D. B., Frazer, A. C., Montgomery, R. D., Philip, W. M., and Phillips, M. J. (1967). Modification in the xylose absorption test as an index of intestinal function. Gut, 8, 348-353. 